\title{
FOTOGRAFI PONSEL (Smartphone) SEBAGAI SARANA MEDIA DALAM PERKEMBANGAN MASYARAKAT MODERN
}

\author{
Muhammad Rusdi Tanjung \\ Prodi Desain Komunikasi Visual \\ Fakultas Seni dan Desain Universitas Potensi Utama \\ rsd.adi@gmail.com
}

\begin{abstract}
Abstrak
Perkembangan teknologi dan ide yang terjadi dalam bidang fotografi sangat berpengaruh terhadap karakteristik dan hasil karya fotografi di jaman sekarang. Kinerja hardware kamera yang disematkan pada smartphone semakin hari semakin baik dengan kualitas hasil gambar yang mampu di tangkap juga semakin memanjakan mata penggunanya. Sebuah foto memiliki nilai dokumentasi karena mampu merekam sesuatu yang tidak mungkin akan terulang kembali. Dengan dukungan kamera yang disematkan pada smartphone, sekarang ini semua orang adalah fotografer, karena mereka mampu menghasilkan foto dengan kualitas yang bagus. Aktivitas fotografi saat ini tidak lagi harus menggunakan kamera khusus, tetapi justru lebih banyak menggunakan kamera dari fasilitas handphone yang digunakan untuk mengabadikan segala kegiatan sehari hari.
\end{abstract}

Kata kunci: fotograpfi, smartphone, Media Sosial Milenial.

\begin{abstract}
Technological developments and ideas that occurred in the field of photography greatly influenced the characteristics and results of photography in today's world. The performance of the camera hardware pinned on the smartphone is getting better and better with the quality of the images that are able to be captured and also spoil the eyes of the users. A photo has documentation value because it is able to record something that is unlikely to happen again. With the support of cameras embedded in smartphones, now everyone is a photographer, because they are able to produce good quality photos. Photography activities at this time no longer have to use special cameras, but instead use more cameras than cellphone facilities that are used to capture all days activities.
\end{abstract}

Keywords: fotography, smartphone

\section{PENDAHULUAN}

Perkembangan teknologi dibidang fotografi telah menyebar luas ke berbagai penjuru dunia serta merambah luas pada kehidupan masyarakat. Perkembangan dunia fotografi semakin luas dan mudah. Khususnya fotografi smartphone perkembangannya semakin berkualitas dengan megapixel yang semakin tinggi, sehingga menghasilkan gambar yang semakin berkualitas. Penggunaan smartphone telah menjadi gaya hidup kaum milenial. Hasil fotografi selain mudah diingat, terkadang memiliki peran penting dan selalu menarik untuk dilihat dan diamati karena memiliki nilai dokumentasi yang tinggi. Sebuah foto mampu merekam sesuatu yang tidak mungkin dapat terulang kembali, dapat berupa peristiwa atau kegiatan manusia, suasana alam, gambaran kehidupan pribadi, atau peristiwa seni dan budaya. 
Melalui foto, orang dapat terpikat pada sebuah objek yang ada didalamnya, mulai dari produk, makanan dan minuman, kegiatan olahraga, infrasturktur, hingga produk hasil industri. Dari hal tersebut berkembang luas istilah foto mampu berbicara. Karena dari sebuah gambar foto orang yang melihatnya dapat merasakan hingga terhanyut dalam peristiwa yang tergambar pada foto tersebut. Dari sini fotografi dapat dikatakan sebagai hasil karya seni yang dapat dilihat diberbagai bidang kehidupan manusia.

Perkembangan dalam pemahaman teori fotografi seiring dengan perkembangan teknologi fotografi mulai dari era pra-fotografi, fotografi analog, fotografi digital, hingga fotografi kamera mirrorless. Perkembangan teknologi pada bidang fotografi pada jaman sekarang sangat berpengaruh terhadap ide, karakteristik dan hasil karya fotografi. Hal ini terlihat dari semakin baiknya perkembangan teknologi mekanisme kamera, mulai dari yang manual hingga digital, serta perkembangan perangkat lunak (software) yang digunakan dalam mengolah hasil karya fotografi. Seiring dengan perkembangan teknologi tersebut, teknik dasar fotografi yang digunakan hingga perinsip kerja kamera yang tersebar di pasaran masih sesuai dengan perinsip dasar yang sama.

Fotografi biasanya diaplikasikan sebagai keperluan dokumentasi. Menurut Sudarma (2014:2) memberikan pengertian bahwa media foto adalah salah satu media komunikasi, yakni media yang bisa digunakan untuk menyampaikan pesan/ide kepada orang lain. Media foto atau istilahkan dengan fotografi merupakan sebuah media yang bisa digunakan untuk mendokumentasikan suatu momen atau peristiwa penting.

Contohnya dalam kegiatan keluarga, jurnalistik, hingga pengarsipan dalam lembaga, untuk keperluan relasi dalam kehidupan sosial, misalnya snapshot dan fotografi selebriti, persuasi komersial, seperti halnya fotografi dalam dunia fashion. Fotografi juga dipakai untuk keperluan eksplorasi kreatif maupun reflektif, seperti halnya dalam fotografi seni yang menghasilkan gambar dengan teknik pengambilan gambar dengan memanfaatkan fungsi waktu, misalnya air terjun yang terlihat seperti kapas, cahaya lampu yang terlihat menjadi garis-garis abstrak hingga membentuk tulisan.

Bull (2009:141) berpendapat bahwa setelah pengadopsiannya oleh para konseptualis pada tahun 1980, fotografi menjadi medium pilihan bagi seniman dalam skala yang luas dari akhir abad 20-an sampai awal abad 21. Untuk menikmati hasil foto yang baik dan menarik memang sangat mengasyikkan, tetapi untuk menghasilkannya dibutuhkan perencanaan dan konsep yang baik pula. Setiap orang dapat mengambil gambar dengan kamera dan merekam setiap objek untuk difoto, namun tidak jarang gambar yang dihasilkan tidak sesuai dengan harapan. Sangat disayangkan apabila sebuah momen, khususnya yang jarang terjadi, difoto seadanya tanpa memperhitungkan segi teknis dan nilai artistik, sehingga gambar yang dihasilkan menjadi tidak bermakna.

\section{STUDI LITERATUR}

Menurut Bull (2010:5) kata dari fotografi berasal dari dua istilah yunani: photo dari phos (cahaya) dan graphy dari graphe (tulisan atau gambar). Maka makna harfiah fotografi adalah menulis atau menggambar dengan cahaya. Dengan ini maka identitas fotografi bisa digabungkan menjadi kombinasi dari sesuatu yang terjadi secara alamiah (cahaya) dengan kegiatan yang diciptakan oleh manusia dengan budaya (menulis dan menggambar/melukis). Sudjojo (2010), mengemukakan bahwa pada dasarnya fotografi adalah kegiatan merekam dan memanipulasi cahaya untuk mendapatkan hasil yang kita inginkan. Fotografi dapat dikategorikan sebagai teknik dan seni. 
Dalam bukunya Jurnalistik Foto: Suatu Pengantar, Gani \& Kusumalestari (2014:4) mengutip dari Sudjojo (2010:vi) bahwa fotografi sebagai teknik adalah mengetahui caracara memotret dengan benar, mengetahui cara-cara mengatur pencahayaan, mengetahui cara-cara pengolahan gambar yang benar, dan semua yang berkaitan dengan fotografi sendiri. Sedangkan fotografi sebagai karya seni mengandung nilai estetika yang mencerminkan pikiran dan perasaan dari fotografer yang ingin menyampaikan pesannya melalui gambar/foto. Fotografi tidak bisa didasarkan pada berbagai teori tentang bagaimana memotret saja karena akan menghasilkan gambar yang sangat kaku, membosankan dan tidak memiliki rasa.

Dalam bukunya, Gani \& Kusumalestari (2014:6) mengatakan: Rasanya tidak ada media massa cetak (surat kabar, tabloid, dan majalah) di negeri ini yang tidak menyertakan foto dalam setiap terbitannya. Foto seringkali menjadi daya tarik bagi pembaca sebelum membaca berita. (quote) kedudukan karya foto di sini adalah sebagai daya tarik, maka esensi dari karya foto dalam jurnalistik adalah sebagai pelengkap/penunjang dari sebuah berita.

Sumardjo (2000:166) menuliskan : penciptaan karya seni memang merupakan kerja pengungkapan iri, ekspresi diri, dalam suatu wujud benda seni. Dari definisi di atas, maka seni dalam penciptaannya adalah suatu media bagi seseorang untuk mengungkapkan; berekspresi.

Hauskeller dalam seni-apa itu? (2015:69) menuliskan: Benjamin menganggap fotografi dan film sebagai bentuk seni inovatif yang menggantikan bentuk-bentuk seni lama seperti lukisan dan sandiwara.

Bate mengungkapkan (2009:144) ketika siapapun berbicara tentang pengaruh dari medium fotografi pada seni (atau seni pada fotografi), penggambaran umum dari perubahan sosial ini dalam penciptaan gambar visual perlu diingat dan dikukuhkan dalam pikiran.

\section{METODE PENELITIAN}

Metode penelitian menggunakan metode kualitatif dengan pendekatan studi literatur berdasarkan pengumpulan data melalui buku-buku mengenai teknik dasar dalam fotografi dan sumber dari Internet mengenai teori-teori dasar fotografi, keunggunalan kamera digital dengan kamera smartphone, dan peranan kamera smartphone menjadi sarana kegiatan social media kaum millennial.

\section{PEMBAHASAN}

\section{Fotografi Smartphone}

Kamera memiliki fungsi untuk menangkap gambar dari apa yang terlihat didepannya, kemudian di catak kedalam lembaran kertas. Menurut Sir John Herschel (1839) mengungkapkan istilah fotografi berasal dari bahasa Yunani : phos yang berarti cahaya dan graphein yang berarti menggambar, dapat diartikan menjadi menggambar dengan cahaya. Teknologi fotografi digital sebagai kombinasi teknologi optik mekanik dan 
komputer. Munculnya teknologi digital mampu merefleksikan momen, identitas, maupun proses fotografis.

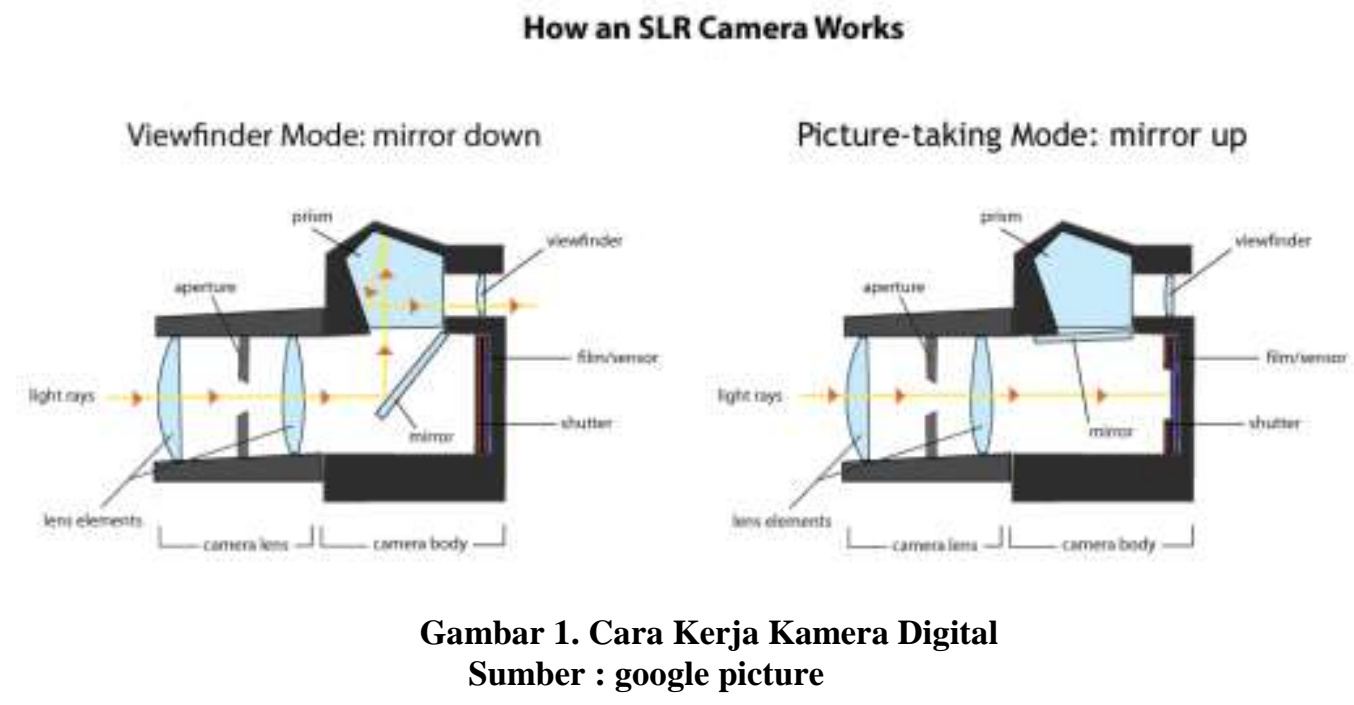

Teknologi kamera terus berevolusi hingga dapat menyatu dengan perangkat telephone selular atau lebih akrab dikenal smartpone, sehingga lebih praktis dan dapat digunakan kapan saja. Pengguna dapat mengabadikan setiap moment tanpa harus menyiapkan peralatan fotografi untuk mencari moment yang tepat. pencinta fotografi smartphone dimanjakan dengan perkembangan teknologi perangkat kamera yang terdapat didalamnya.

Produsen smartphone berlomba-lomba dalam menghasilkan kualitas kamera mereka, setiap vendor memberikan keunggulan vitur yang dimiliki, hasil gambar dan video yang mampu dihasilkan dari produk mereka, dengan harapan mendapat apresiasi yang tinggi dari masyarakat millenial. Dengan kemampuan resolusi pixel kamera yang menyaingi resolusi hasil kamera DSLR, memastikan kepada penggunannya untuk tangkapan gambar dengan kualitas hasil yang baik dan tanpa harus melalui proses editing software komputer. Hal tersebut memberikan keunggulan lebih bagi penggunanya, dengan perangkat yang ringan dan mudah dibawa mampu untuk menghasilkan tangkapan gambar yang berkualitas.

Kinerja hardware kamera yang disematkan pada smartphone semakin hari semakin tinggi dengan kualitas hasil gambar yang mampu di tangkap juga semakin memanjakan mata penggunanya, begitu pula pengaruhnya terhadap perekaman video. Video yang dihasilkan oleh smartphone juga mengalami peningkatan terhadap kualitas video yang dihasilkan, bahkan beberapa vendor terkenal berlomba-lomba dalam menghasilkan video berkualitas full High Definition dengan resolusi pixel yang tinggi. 


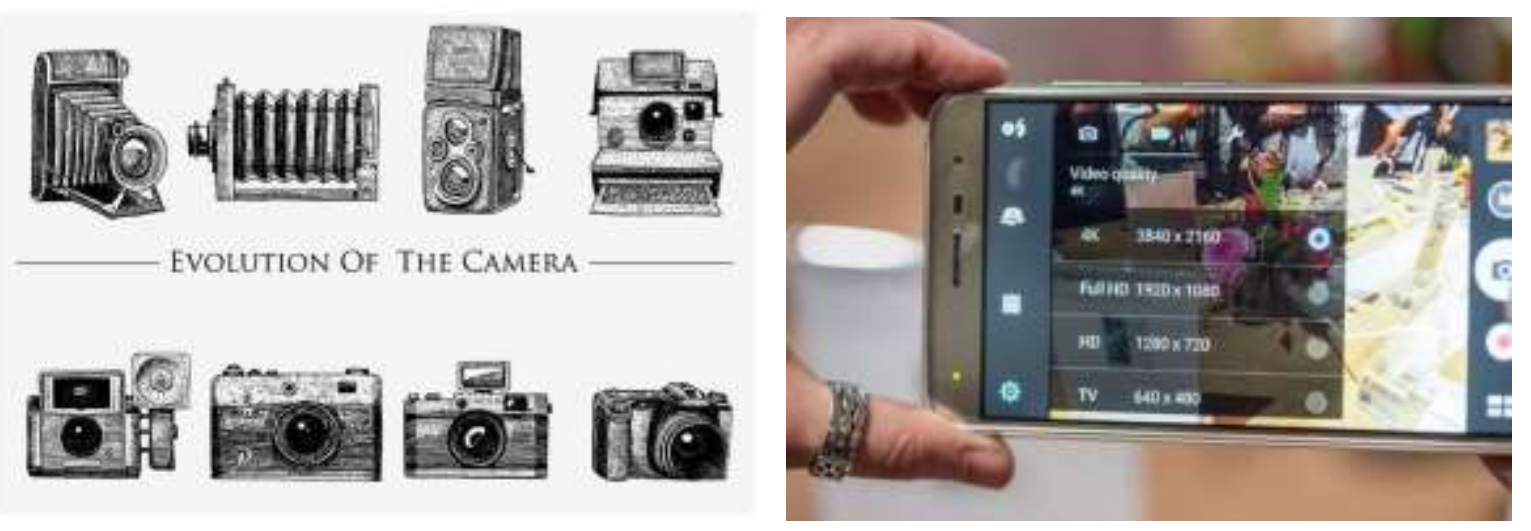

Gambar 2. Teknologi Kamera Smartphone

Sumber : google picture

Menurut Thomas Munro (1969) Seni fotografi bisa dikatakan sebagai kegiatan penyampaian pesan secara visual dari pengalama yang dimiliki seniman/fotografer kepada orang lain dengan tujuan orang lain mengikuti jalan pikirannya. Supaya tercapai proses penyampaian pesan ini maka harus melalui beberapa persyaratan komunikasi yang baik, yaitu konsep AIDA (Attention -Interest-Desire - Action) atau Perhatian - Ketertarikan Keinginan - Tindakan.

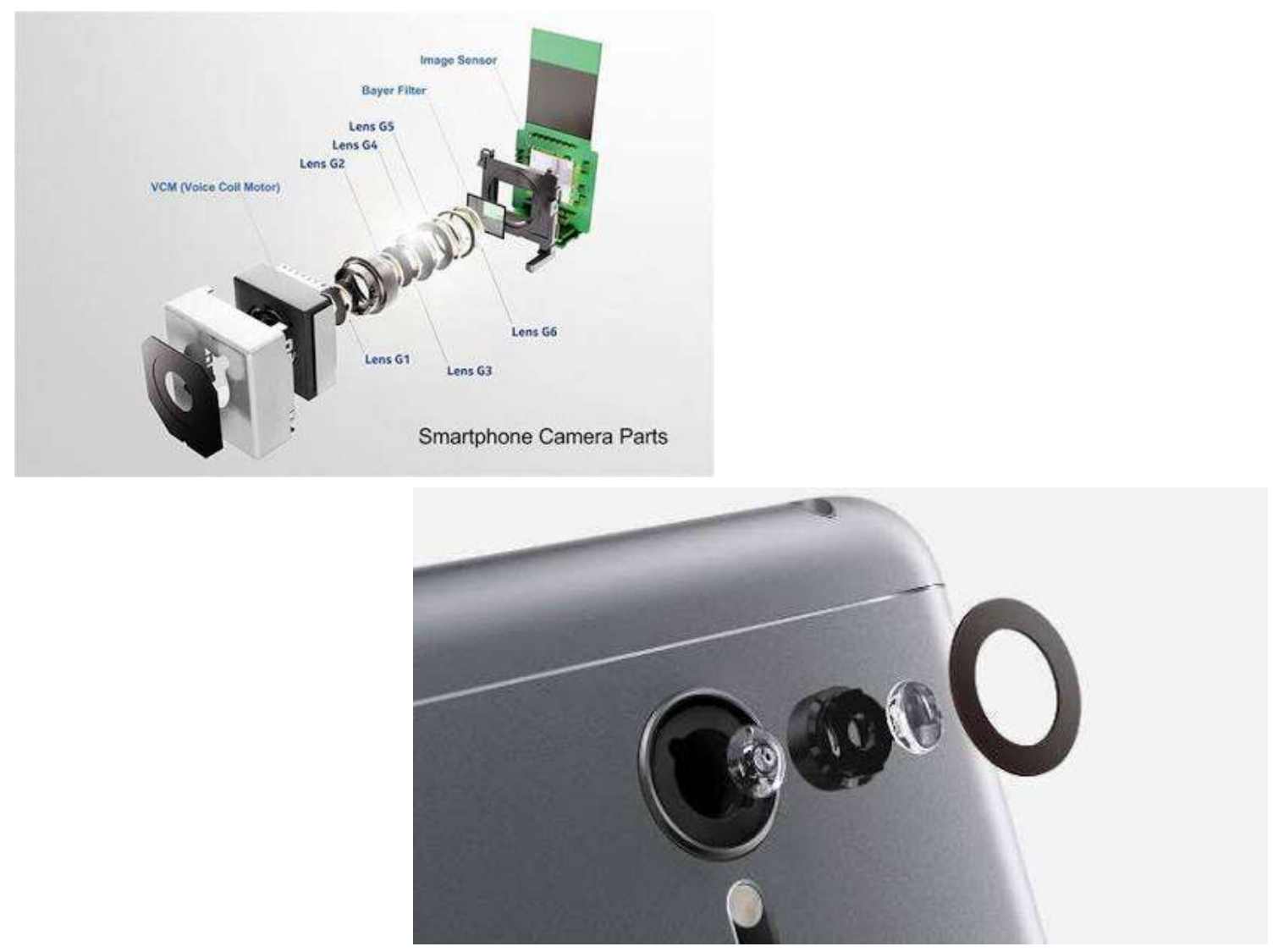

Gambar 3. sistem kerja kamera DSLR dengan kamera Smartphone Sumber : google picture 


\section{Budaya Sosial}

Budaya visual masa kini adalah perhatian pada hubungan peristiwa-peristiwa visual, yaitu informasi, makna-makna, dan kesenangan yang dicari melalui perangkat teknologi visual. Dengan teknologi visual, segala bentuk peralatan dirancang khusus untuk melihat atau untuk menangkap gambaran mengenai alam, dari lukisan hingga gambargambar melalui media televisi atau internet (Mirzoeff, 2002:3). Hal ini terjadi dalam kehidupan sehari-hari dan menjadi kebiasaan (habit). Disebut dengan budaya karena ada kemampuan manusia untuk mengajar dirinya sendiri (Kant dalam Peursen, 1976:102). Komunikasi dan interaksi terjadi karena orang lain mengapresiasi hasil-hasil visual tersebut melalui media tertentu.

Gaya hidup pada dasarnya merupakan suatu perilaku yang mencerminkan masalah apa yang sebenarnya yang ada dalam alam pikir seseorang yang cenderung berbaur dengan berbagai hal yang terkait dengan masalah emosi dan psikologis. Menurut Well \& Tigert dalam Susanto (http://www.jakartaconsulting.com/art-01-11.htm, diakses pada 8 juni 2016), perilaku ini dapat diamati atau diukur dengan sistem AIO (Activities, Interest, and Opinion) dalam pengertian: (1) bagaimanakah mereka menggunakan waktu dalam kehidupan sehari-hari, (2) apa yang menjadi minat atau apa yang ada di sekeliling mereka yang dianggap penting dalam kehidupan dan berinteraksi, (3) bagaimana pendapat atau opini memandang diri sendiri terhadap dunia di sekitar mereka, dan (4) karakteristik dasar kelompok tersebut umumnya dapat didasarkan pada wilayah geografis.
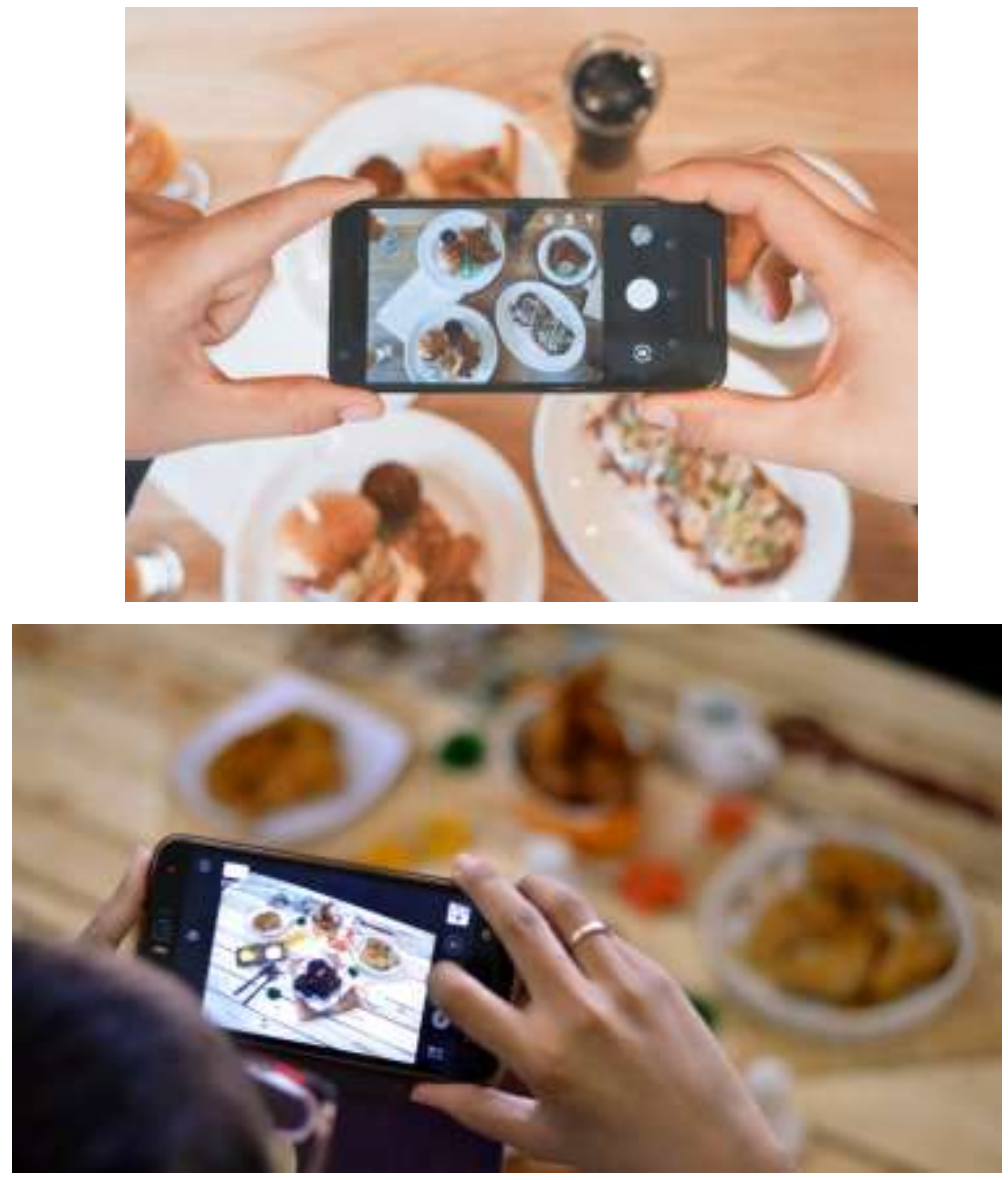

Gambar 4. fotografi makanan dengan kamera smartphone Sumber : google picture

Pada foto semi digital proses pemotretan, gambar masih direkam pada film yang berseluloid, kemudian film yang sudah merekam gambar diproses dan menghasilkan 
gambar kemudian diproses lagi melalui scanner menjadi data digital untuk di simpan dalam disket atau hardisk. Era modernisasi fotografi menampakkan perkembangan yang cukup besar melalui fotografi digital, aktivitas perekaman gambar dengan teknologi yang dikendalikan oleh prosesor layaknya sebuah komputer, dengan koneksi media ruang penyimpanan (hard drive) yang memiliki kapastas besar untuk menampung hasil gambar yang dihasilkan oleh kamera dengan dukungan resolusi pixel yang besar.

Dengan dukungan kualitas kamera yang disematkan pada smartphone, sekarang ini semua orang adalah fotografer, karena mereka mampu menghasilkan foto yang bagus. Semakin banyak peristiwa yang dapat terabadikan dalam fotografi, semakin banyak pula foto yang tercetak hingga orang memerlukan album yang memiliki tematema khusus. Saat ini hampir semua media sosial memfasilitasi penggunanya untuk posting fotografi. Kebanyakan karya fotografi di jejaring sosial dihasilkan dari gadget yang dapat terhubung dengan internet, dikenal saat ini dengan nama smartphone.

Aktivitas fotografi saat ini tidak lagi harus menggunakan kamera khusus, tetapi justru lebih banyak menggunakan kamera dari fasilitas handphone yang digunakan untuk mengabadikan segala kegiatan sehari hari. Bahkan juga mengabadikan diri yang populer dengan istilah selfie untuk kemudian mengunggahnya ke jejaring sosial. Dengan dukungan teknologi, yaitu smartphone yang digunakan dalam kehidupan sehari-hari, aktivitas fotografi saat ini tidak lagi harus menggunakan kamera khusus. Aktivitas fotografi ini dapat dilakukan di mana saja, kapan saja, atau bahkan dalam situasi apa pun pasti ada kesempatan untuk membuat foto kemudian di-upload ke media sosial baik sebagai foto profil maupun sebagai status aktivitas yang dijalani dalam keseharian.
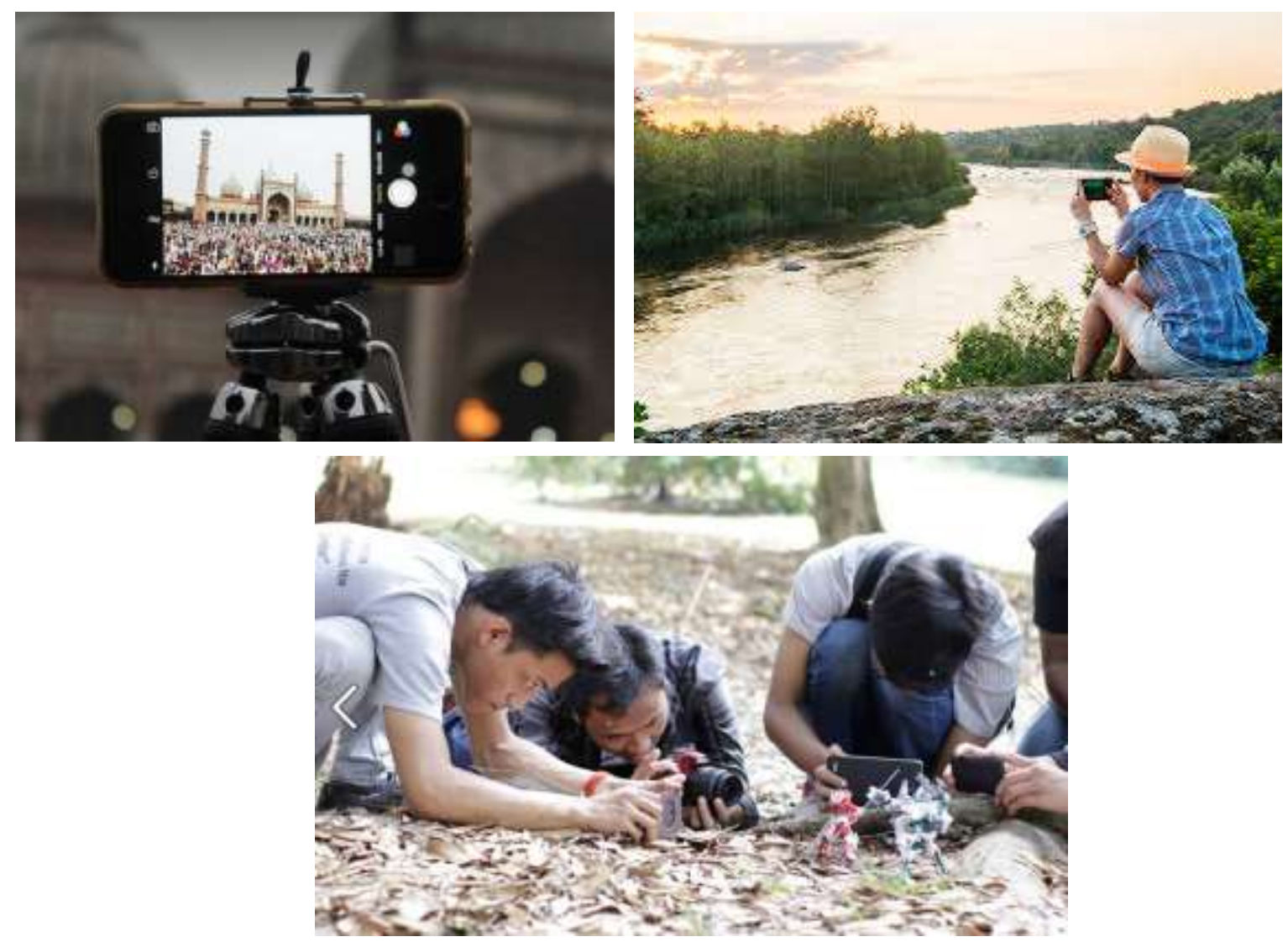

Gambar 5. fotografi ponsel yang berkembang di Masyarakat Sumber : google picture 


\section{Media Sosial}

Pengalaman memotret menggunakan kamera telepon seluler membuat sebagian pencintanya membentuk wadah untuk saling berbagi pengalaman dan teknik-teknik dalam pengambilan gambar untuk menghasilkan karya sebaik mungkin, biasanya mereka berkumpul dalam kelompok-kelompok sosial dalam dunia maya (social media), yang didalamnya berisikan hasil pengambilan gambar dari masing-masing anggotanya, dengan harapan mendapat kritikan maupun saran dari teman-teman sesama anggotanya untuk saling berbagi wawasan, dan bahkan sering pula berkumpul secara langsung dalam kegiatan gathering untuk saling mengenal lebih dekat antara sesama anggota komunitasnya. Tak jarang anggota komunitas-komunitas seperti ini memiliki jumlah anggota yang terdiri dari berbagai wilayah, sehingga terbentuklah komunitas regional, dengan demikian setiap anngota dapat lebih mudah menjangkau maupun memperluas persaudaraan sesama anggota dengan lokasi yang berdekatan dengan tempat tinggal mereka.

Kebutuhan akan media untuk mempopulerkan hasil karya fotografi semakin berkembang, banyak aplikasi social media on-line yang menyediakan fitur berbagi sebagai fokus utama aplikasi tersebut dalam merebut simpatik penggunanya, aplikasi sejenis ini memiliki keunggulan untuk menampilkan hasil karya foto yang dapat diupload oleh penggunanya secara langsung dengan mengaktifkan fitur kamera yang dimiliki, bahkan terdapat pula fitur foto maupun video editor layaknya hasil editing professional, penyematan fitur lokasi, emoticon, dan teks menjadikan penggunanya semakin dimanjakan untuk dapat bereksplorasi menghasilkan karya fotografi.

Adapula yang merasa kurang puas atas fitur yang dimiliki oleh kamera smartphone, mereka berusaha melakukan percobaan dengan memanfaatkan lensa kamera lama yang di ambil dan dimodifikasi sedemikian rupa untuk dapat di gunakan pada telepon seluler. Selain itu, adapula yang mengembangkan mounting lensa agar dapat terkoneksi dengan lensa kamera DSLR sehingga mampu menangkap objek gambar layaknya kamera DSLR saat mengambil gambar, mulai dari fungsi zoom dan fokus objek, hingga hasil gambar yang ditangkap.

\section{Masyarkat Millennial}

Mata seorang fotografer yang sudah terlatih mampu menangkap berbagai macam keindahan dimana saja, bahkan terhadap obyek yang mudah ditemukan dalam kehidupan sehari-hari sekalipun. Tanpa memiliki kemampuan Teknik fotografi yang baik, sebuah obyek yang terlihat sangat menarik dapat tampil biasa saja, atau menjadi tidak menarik sama sekali untuk dilihat, begitu pula sebaliknya, sebuah objek yang terlihat biasa saja akan memiliki daya tarik sendiri pada orang yang melihatnya jika diambil dengan kemampuan teknik fotografi yang baik.

Pengguna smartphone yang selalu terhubung dengan internet memiliki kebiasaan untuk mengunggah hasil tangkapan gambar miliknya ke jejaring sosial. Mereka ingin hasil pengambilan gambarnya dapat dilihat banyak orang serta mendapat tanggapan, baik tanggapan berupa pujian atau kritik dari orang lain. Bermacam cara dilakukan masyarakat millennial terhadap hasil karya fotografi mereka, ada yang menjadikan fotografi sebagai hobi mereka untuk menghasilkan karya, Adapula yang menjadikan karya hasil foto mereka sebagai media untuk mempromosikan diri layaknya memiliki kemampuan setingkat fotografer profesional dan tak jarang yang sukses dan mampu memperoleh penghasilan dari karya fotografi mereka walaupun hanya berbekal kamera smartphone. 


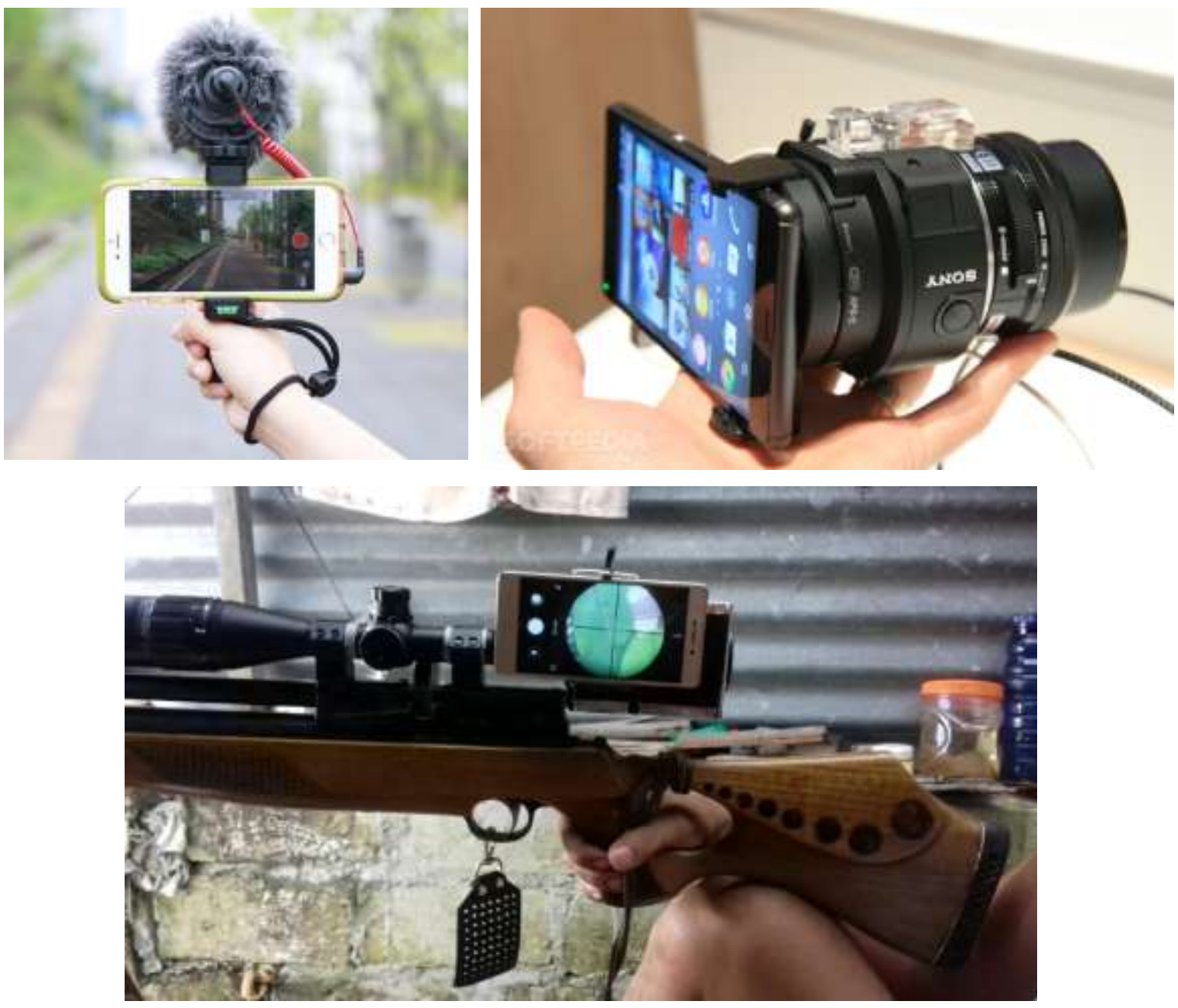

Gambar 6. pemanfaatan Kamera Smartphone dalam berbagai aktivitas Sumber: Google Picture

Selain sebagai media fotografi, pengguna smartphone juga memanfaatkan fasilitas kamera tersebut untuk kebutuhan videografi yang hasilnya juga tak kalah hebat dari camcorder yang pernah berkembang pesat pada era sebelumnya. Dengan demikian, semakin banyak aktifitas pengambilan gambar yang dapat dilakukan oleh perangkat ini, seperti layaknya julukan ponsel pintar (smartphone).

\section{KESIMPULAN}

Gaya hidup secara luas didefinisikan sebagai cara hidup yang diidentifikasikan oleh bagaimana seseorang menghabiskan waktu mereka, seperti aktivitas, apa yang mereka anggap penting dalam lingkungannya atau ketertarikan, dan apa yang mereka pikirkan tentang diri mereka sendiri dan juga dunia di sekitarnya. Gaya hidup (lifestyle) secara sosiologis dengan pengertian terbatas merujuk pada gaya hidup khas suatu kelompok tertentu.

Perkembangan teknologi pada kamera Smartphone mampu menjadikan setiap penggunanya secara psikis memiliki kemampuan dalam fotografi, dimana dengan peran hardware dan software yang dimiliki mampu memberikan hasil dengan kualitas gambar yang baik. 
Aktivitas pariwisata tidak terlepas dari dokumentasi sebagai sebuah sarana untuk mengenang kejadian/peristiwa kegiatan berwisata. Foto/gambar merupakan produk dari aktivitas fotografi. seiring dengan berjalannya waktu, berwisata saat ini merupakan sebuah keharusan bagi kebanyakan orang untuk menunjukkan eksistensi diri. Dorongan seseorang untuk menunjukkan eksistensi diri yang tidak terlepas dari berkembangnya teknologi dan informasi saat ini. Wisatawan saat ini rajin mengunggah foto-foto selama kunjungan wisata melalui media sosial. Meskipun pada awalnya hal ini merupakan ekspresi diri atau cerminan suasana hati, secara fungsional sebenarnya penuh makna informatif.

Selain fotografi dalam kaitan wisata, fotografi ponsel juga berkembang dimasyarakat dalam kegiatan kebersamaan, dengan adanya perkumpulan pencinta fotografi yang dibuat dalam komunitas, didalamnya mereka saling berbagi informasi seputar teknik fotografi serta memanfaatkan fitur-fitur, hingga membuat ulasan kekurangan dan kelebihan sebuah kamera foto yang terdapat dalam sebuah smartphone. Komunitas ini kadang kala membentuk kegiatan aktif seperti foto bersama yang biasa di sebut hunting bersama.

Era teknologi smartphone yang semakin baik dari segi kualitasnya membuat masyarakat semakin memiliki banyak pilihan terhadap gadget yang dapat mereka pilih sesuai dengan tingkat kebutuhannya. Dengan dukungan teknologi, yaitu smartphone yang digunakan dalam kehidupan sehari-hari, aktivitas fotografi saat ini tidak lagi harus menggunakan kamera khusus. Aktivitas fotografi ini dapat dilakukan di mana saja, kapan saja, atau bahkan dalam situasi apa pun pasti ada kesempatan untuk membuat foto kemudian di-upload ke media sosial baik sebagai foto profil maupun sebagai status aktivitas yang dijalani dalam keseharian.

\section{DAFTAR PUSAKA}

[1] Astrid Susanto, 1984. Komunikasi D alam Teori dan Praktek, Bina Cipta, Jakarta,.

[2] Beaumont Newhall, 1982. The History of Photography, the Museum of Modern Art, New York,.

[3] Marien, Mary Warner, 2014. Photography: A Culturel History $4^{\text {th }}$ ed. London: Laurence King Publishing, Ltd.,

[4] Markow, Paul. 1999. Advertising Photography. New York: Amherst Media Inc. Buffalo.

[5] Herlina. Yekti, 2003. Kreativitas Dalam seni Fotografi. jurnal NIRMANA Vol. 5, No. 2, Juli 2003: $214-228$

[6] Peiper, J. 1952. Leisure, The Basis of Culture. Trans. A. Dru. New York: Parthenon Books.

[7] Surisman Marah, 1985. Diktat Kuliah; Mengenal Kamera Fotografi, Fakultas Seni Rupa dan Disain, ISI Yogyakarta

[8] Soedjono, Soeprapto. 2009. "Fotografi dalam Konstelasi Budaya Visual Indonesia". Buklet Pengukuhan Guru Besar Prof. Drs. Soeprapto Soedjono. Yogyakarta: BP ISI.

[9] Thomas Munro, 1969. The Art and Their Interrelations, The Press of Case Western Reserve University, Cleveland and London. p.548 


\section{Website}

[10] Effendy , Rifky. Tantangan Fotografi dalam Era Rekayasa Digital. www.kompas.com 12 Mei 2017.

[11] https://www.fisikabc.com/2017/12/kamera.html

[12] https://sains.kompas.com/read/2018/05/24/204343323/ penemuan-yang-mengubahdunia-kamera-pertama-dibuat-cedekiawan-muslim

[13] http://www.jakartaconsulting.com/art-01-11.htm, diakses pada 8 juni 2016 